\title{
Effectiveness Criteria for Interaction Between the Participants of the Educational Production Cluster Within PDA
}

\author{
https://doi.org/10.3991/ijet.v16i08.19505 \\ Vladislav Lizunkov $^{(\bowtie)}$, Marina Morozova \\ Tomsk Polytechnic University, Tomsk, Russia \\ vladeslavedrambler.ru \\ Zakharova Alexandra \\ Tomsk State University of Control Systems and Radio Electronics, \\ Tomsk, Russia
}

\begin{abstract}
The current context of the Priority Development Areas (PDA) raises the issues of ensuring the interaction between vocational and higher education organizations and real sector enterprises operating in the city. This paper presents an analysis of Russian and foreign studies to identify the main stakeholders interested in this interaction, as well as the criteria that contribute to determining the effectiveness of joint work to train qualified personnel demanded by the PDA production enterprises.
\end{abstract}

Keywords - Specialists, stakeholders, enterprises, educational institutions, demanded personnel, criteria

\section{Introduction}

The world economy is connected with the intensification of competition, fast change of technologies and an increase of economic uncertainty. It creates demand for new types of competencies, new forms, new methods and technologies of advanced training of professional personnel, with forecasting of labor market needs in specialists.

There is a growing demand for specialists with flexibility and creativity in solving professional tasks, ready both to make independent decisions and to work in conditions of multidisciplinary teams, capable of interacting with various socio-cultural groups and technological environments. Nowadays, the labor market has a strong demand for high-speed education, which trains specialists to solve a narrow range of tasks at a particular workplace. In the conditions of the COVID-19 pandemic, interest in quality distance education services has increased dramatically, bringing educational organizations capable of meeting this need of the population and economy to the forefront. The requirements to the economically active population of the country have changed rapidly in terms of digital competence, independence and personal responsibility in the issues of vocational training, retraining and professional development. 
These circumstances significantly update the issues related to the development of the education system in the Priority Development Areas (PDAs), in particular in monocities, which are the most vulnerable in terms of their existence in a rapidly changing economy. Undoubtedly, the priority comes to the issues of relevance of services provided by educational organizations for education of the population in general and vocational training of citizens, in particular, PDA residents. The analysis of social and economic prerequisites for the development of the PDAs makes it obvious that educational organizations can supply the city or region's economy with labor resources only in conditions of effective interaction with the real sector enterprises operating in the city or region $[1,2,3]$.

\section{Subject and Methods of Research}

According to many researchers involved in educational reform, the interaction between educational organizations and real sector enterprises is one key tool aimed at effective advanced training of professional personnel. In the conditions of created PDAs we speak about educational organizations and enterprises, existing or opening on the PDA. Researchers in scientific literature often turn to the form of production and educational clusters to justify the effectiveness of partnership based on the cluster model $[4,5,6]$.

Discussing the main subjects interested in the existence of production and educational clusters, the authors of the article identify four main stakeholders of interaction, which are both real or potential investors in the training process, and recipients of the education product (it is a graduate for an educational organization, it is an employed specialist for the state, it is a specialist prepared to work for an employer, it is a diploma entitling a person to employment). Such stakeholders include the state, educational organizations, individuals and enterprises of the real economy sector. This article provides a more detailed classification of these stakeholders. The authors of the article consider the effective interaction of these four stakeholders to be the best way to train specialists of the required qualification in a short time, thus meeting the needs of all three interested stakeholder groups.

Studies of many Russian and foreign scientists focus on various aspects of the interaction between educational organizations and production enterprises. Thus, N. S. Bugrova investigates the application of network interaction to the system of further training of teachers and determines its cyclicity and stages [7].

T. A. Zubareva's model of network interaction application in the innovative development of educational organizations differs in its focus on innovative development, considering the interdependence of elements and technology of network interaction [8].

T. B. Pankratova studies joint work of the employment service and universities related to adaptation of graduates on the labor market. She defines the components of network interaction as a unified pedagogical process that includes professional orientation in the environment of general education schools; practice-oriented elective courses; specialized training; educational work in universities to create a professional career; industrial practice; assistance to graduates in adapting to the labor market and 
employment; organization of internships. Her research also confirmed an increase in public satisfaction with such an indicator as the quality of services provided by the employment offices involved in networking with higher education institutions [9].

In the international scientific community, the main vector of studying the processes to transform vocational and higher education in the context of evaluating network interactions with the real economy sector seeks to determine the strategy for changing the scientific and educational activities in specific universities and to search for factors that determine the effectiveness of such interaction $[10,11,12]$. In particular, researchers study the role of education in achieving the goals of economic growth in a knowledge society where there are constant competition and development with continuous changes in economic and political dynamics.

The analysis of Russian and foreign scientific literature on the research problem shows sufficient study of the interaction between educational organizations and production stakeholders based on the cluster approach to regional development. (for example, A.I. Makeeva, M. Portera, T.V. Tsikhan, E.V. Tkachenko, I. P. Smirnova, G. V. Mukhametzyanova, O. N. Oleinikova, R.S. Safina, E.A. Korchagin, D.Yu. Lapygina, A.A. Migranyan, G.A. Koretsky) $[13,14]$.

\section{Survey Results Analysis}

It is impossible to talk about the interaction of educational organizations and production enterprises without analyzing the benefits provided by the integration of science, education and production to the cluster. In the Russian Federation, the current state standards provide for both differentiation and individualization of vocational education, which in turn serve as a basis for the development of scientific, educational and production components of the industrial and educational cluster [15]. The advantages of this integration include:

- Possibility of efficient consumption of all available internal educational and production resources

- Opportunities to ensure the integration of educational content and continuity of educational programs, as well as the creation of cross-cutting training plans that contribute to the reduction of training time and enable production enterprises to participate in the training process [16].

Among the main trends that stimulate the need for the cluster approach in the interaction of educational organizations and enterprises of the real economy, the authors include the following: 
1. A new PDA business needs highly qualified specialists in both production and management issues.

2. PDA production enterprises need a wider range of specialists and have high requirements to the quality of vocational training and education.

3. The regions have a demand for specialists previously belonging to the "elite" areas of training, for example, in international relations and trade, state and municipal administration, banking.

4. The production enterprises need specialists of different levels of training with the advanced training principle applied.

These tendencies form a new vision of modern education for the population, heads of enterprises located in the PDAs and management bodies of these areas:

- Increased understanding about the importance of quality education, both for the development of the individual and for the development of PDA in general

- Changed attitude of students towards education. Thus, today's schoolchildren and students show great independence in learning and educational initiative

- Stakeholders are ready to invest in education, provided that the educational organization produces specialists of the required direction and the required competence level

- Some workers who have received education not demanded in the labor market are ready to invest their own funds in retraining

- There are changes in the nature of interaction between science, education and production in training activities.

The cluster approach itself provides the complex work of interconnected organizations working in professional education and united by the branch feature and relations with partner enterprises of the branch, promotes the integration of science, education and production, and the creation of conditions for the training of personnel at different levels of professional education [17]. In modern conditions, the main difference in the management of such integrity of science, education and production becomes the market mechanism of management which "works from below" according to the conditions of interaction with the enterprises and the initiative of the educational organizations, unlike a command-industry principle with management "from above". It makes this approach the most preferable in the conditions of the modern economy [18].

\section{Conclusion}

During the research the authors developed and substantiated the list of participants (stakeholders) of interaction between educational organizations and real sector enterprises in the PDA context, which identifies: 
a) Organizations and enterprises that are PDA residents or are currently obtaining the status of residents

b) Educational organizations which activity aims at training (advanced training) specialists for PDA enterprises; such organizations should include educational organizations of professional and higher education, educational organizations of additional education, resource centres, training complexes, centres of accreditation and certification, as well as research institutes [19,20]

c) Municipal administration of the PDA, which is a key (central) link in the interaction of all stakeholders. It is a tool that promotes the integration of all participants in the interaction. This category should also include an employment centre concentrating the labour resources of PDA that need to be employed and potential "orders" for labour resources

d) Individuals who are citizens living in PDAs [21].

In their research, the authors pay special attention to developing criteria for the effectiveness of interaction between educational organizations and real sector enterprises in the context of PDAs, as well as determining their importance for each of the stakeholders (Table 1) from the standpoint of "the stakeholder contribution to the effectiveness of PDAs" and "the PDA contribution to the stakeholder's development effectiveness".

Thus, the authors defined a list of criteria for effective interaction between educational organizations and real sector enterprises in the PDA context, which includes:

1. Demand for labour resources. This criterion reflects the level of population employment resulting from the creation of a business on the PDA;

2. Level of physical and psychological well-being of the PDA population residents. This criterion reflects the well-being level of the PDA citizens due to the formation of new enterprises and development of the PDA;

3. Attraction of new investors (support for the development of small and medium businesses) and the availability of mechanisms to facilitate the entry of enterprises into foreign markets. This criterion reflects the quantitative index of establishing PDA enterprises within a given period and their quantitative ratio indicating the activity on the market outside the PDA;

4. Innovation and technology policy (innovation and R\&D incentives). This criterion reflects the level of knowledge-intensive products manufactured at the PDA enterprises and implementation of $R \& D$ projects in quantitative ratio for a certain period;

5. Educational policy (creation of a new training system aimed at the emergence of new professions and specialties). In determining the indicators of this criterion and its corresponding levels, the authors plan to consider quantitative indicators that correlate with the number of production PDA enterprises; a number of new educational programs at the request of business; a number of new professions and specialties in demand at the PDA enterprises; a number of trained specialists. 
Table 1. Criteria for the interaction of stakeholders in the context of PDA

\begin{tabular}{|c|c|c|c|c|c|c|}
\hline \multirow[b]{2}{*}{$\begin{array}{l}\text { Participant } \\
\text { of indus- } \\
\text { trial and } \\
\text { educational } \\
\text { cluster (net- } \\
\text { work) of } \\
\text { PDA }\end{array}$} & \multicolumn{6}{|c|}{$\begin{array}{l}\text { Criteria for interaction between PDA participants } \\
\text { (in accordance with "stakeholders' contribution to the development effectiveness of } \\
\text { PDA/PDA contribution to the stakeholders' development efficiency") }\end{array}$} \\
\hline & $\begin{array}{l}\text { Demand for } \\
\text { labor re- } \\
\text { sources }\end{array}$ & $\begin{array}{l}\text { Level of } \\
\text { physical } \\
\text { and psy- } \\
\text { chological } \\
\text { well-being } \\
\text { of citizens }\end{array}$ & $\begin{array}{l}\text { Attracting } \\
\text { new inves- } \\
\text { tors (sup- } \\
\text { porting the } \\
\text { develop- } \\
\text { ment of } \\
\text { small and } \\
\text { medium en- } \\
\text { terprises) }\end{array}$ & $\begin{array}{l}\text { Facilitation } \\
\text { of enter- } \\
\text { prises' entry } \\
\text { into foreign } \\
\text { markets }\end{array}$ & $\begin{array}{l}\text { Innovation } \\
\text { and tech- } \\
\text { nology pol- } \\
\text { icy (inno- } \\
\text { vation and } \\
\text { R\&D in- } \\
\text { centives) }\end{array}$ & $\begin{array}{l}\text { Educational } \\
\text { policy } \\
\text { (creation of } \\
\text { a new train- } \\
\text { ing system } \\
\text { aimed at } \\
\text { the emer- } \\
\text { gence of } \\
\text { new profes- } \\
\text { sions and } \\
\text { specializa- } \\
\text { tions). }\end{array}$ \\
\hline $\begin{array}{l}\text { Stakehold- } \\
\text { ers } \\
\text { (business } \\
\text { representa- } \\
\text { tives) }\end{array}$ & $\begin{array}{l}\text { The estab- } \\
\text { lishment of } \\
\text { new enter- } \\
\text { prises in } \\
\text { the PDAs } \\
\text { causes a } \\
\text { shortage of } \\
\text { personnel, } \\
\text { which in } \\
\text { turn solves } \\
\text { the problem } \\
\text { of employ- } \\
\text { ment of the } \\
\text { PDA resi- } \\
\text { dents. } \\
\text { The PDA, } \\
\text { in turn, cre- } \\
\text { ates condi- } \\
\text { tions for es- } \\
\text { tablishing a } \\
\text { new busi- } \\
\text { ness, which } \\
\text { solves the } \\
\text { problem of } \\
\text { employ- } \\
\text { ment in } \\
\text { these areas. }\end{array}$ & $\begin{array}{l}\text { By creating } \\
\text { and open- } \\
\text { ing new en- } \\
\text { terprises, } \\
\text { business } \\
\text { contributes } \\
\text { to the em- } \\
\text { ployment } \\
\text { of citizens } \\
\text { and resultes } \\
\text { in improv- } \\
\text { ing the } \\
\text { physical } \\
\text { and psy- } \\
\text { chological } \\
\text { well-being } \\
\text { of the pop- } \\
\text { ulation of } \\
\text { PDA. } \\
\text { The PDA } \\
\text { provides, in } \\
\text { return, a } \\
\text { number of } \\
\text { preferences } \\
\text { for busi- } \\
\text { ness, cre- } \\
\text { ates condi- } \\
\text { tions for } \\
\text { the devel- } \\
\text { opment of } \\
\text { companies } \\
\text { and, as a } \\
\text { result, for } \\
\text { the growth } \\
\text { of physical } \\
\text { and psy- } \\
\text { chological } \\
\text { well-being } \\
\text { of citizens. }\end{array}$ & $\begin{array}{l}\text { The busi- } \\
\text { ness en- } \\
\text { tered in the } \\
\text { PDA is in- } \\
\text { terested in } \\
\text { the enter- } \\
\text { prises of } \\
\text { the accom- } \\
\text { panying di- } \\
\text { rections of } \\
\text { activity. It } \\
\text { is not inter- } \\
\text { ested in en- } \\
\text { terprises } \\
\text { producing } \\
\text { similar } \\
\text { goods and } \\
\text { services. } \\
\text { The PDA } \\
\text { provides, in } \\
\text { return, a } \\
\text { number of } \\
\text { preferences } \\
\text { for the } \\
\text { business of } \\
\text { different } \\
\text { levels, cre- } \\
\text { ates condi- } \\
\text { tions for } \\
\text { the devel- } \\
\text { opment of } \\
\text { companies }\end{array}$ & $\begin{array}{l}\text { The PDA } \\
\text { provides a } \\
\text { number of } \\
\text { preferences } \\
\text { for the } \\
\text { business of } \\
\text { different } \\
\text { levels, thus } \\
\text { creating } \\
\text { conditions } \\
\text { to facilitate } \\
\text { the entry of } \\
\text { enterprises } \\
\text { into foreign } \\
\text { markets. }\end{array}$ & $\begin{array}{l}\text { The PDA } \\
\text { business is } \\
\text { interested } \\
\text { and makes } \\
\text { a lot of ef- } \\
\text { fort to stim- } \\
\text { ulate inno- } \\
\text { vation and } \\
\text { develop co- } \\
\text { operation } \\
\text { within the } \\
\text { cluster in } \\
\text { the R\&D } \\
\text { area. } \\
\text { PDA, in } \\
\text { turn, uses } \\
\text { various in- } \\
\text { struments } \\
\text { of interac- } \\
\text { tion be- } \\
\text { tween R\&D } \\
\text { and busi- } \\
\text { ness to im- } \\
\text { plement an } \\
\text { innovative } \\
\text { and techno- } \\
\text { logical pol- } \\
\text { icies of the } \\
\text { areas. }\end{array}$ & $\begin{array}{l}\text { The PDA } \\
\text { business is } \\
\text { an incen- } \\
\text { tive to } \\
\text { change the } \\
\text { educational } \\
\text { system, be- } \\
\text { cause it is a } \\
\text { key cus- } \\
\text { tomer for } \\
\text { specialists } \\
\text { of a new } \\
\text { level and } \\
\text { new direc- } \\
\text { tions. } \\
\text { The PDA, } \\
\text { in turn, of- } \\
\text { fers tools } \\
\text { for interac- } \\
\text { tion in the } \\
\text { system of } \\
\text { partners } \\
\text { business } \\
\text { administra- } \\
\text { tion - indi- } \\
\text { vidual-edu- } \\
\text { cational in- } \\
\text { stitution }\end{array}$ \\
\hline
\end{tabular}


As a perspective of the research, the authors see the development of tools and methods to diagnose the effectiveness of interaction between educational organizations and real sector enterprises in the PDA context, as well as the development of conditions that promote the effectiveness of interaction between the state, educational organizations, individuals and real sector enterprises in the framework of socio-economic development of the PDA and improving the well-being of residents.

\section{Acknowledgement}

The research was carried out with the financial support of the RFBR in the framework of research project No. 19013-00486A.

Parts of the research work which describe the subject of the investigation and the methodology of the study were supported by the Russian Science Foundation (project No 19-78-00018).

\section{References}

[1] Ulitskaya, N.Yu.; Akimova, M.S.; Kokoreva, T.P. Priority social and economic development area as a factor of territory development and attractiveness for resident // Business strategies. 2017. No. 10 (42). Pp. 12-16. https://doi.org/10.17747/ 2311-7184-2017-10-12-16

[2] Khardaev N. E., Platonov V. A. Priority social and economic development areas as the main mechanism for development of the Far East and Baikal region // Economy and entrepreneurship. 2015. No. 12-3 (65). Pp. 355-357.

[3] Lizunkov V. G., Morozova M. V., Zakharova A. A. On social partnership in the system of advanced training for monocities of Priority Development Area: educational and sectoral clusters // Economics of Education. 2019. No. 3 (112). Pp. 81 93.

[4] Bakhvalova Z. A. System analysis and information modelling of the interaction between stakeholders of the industrial and educational cluster / dissertation author's abstract for the degree of candidate of technical sciences // Irkutsk State University of Railways. Irkutsk, 2008

[5] Kuimov, V.V.; Tolstoy, D.A.; Kuimov, A.O. Research, production and educational clusters on training specialists for the innovation projects // Innovations in science. 2016. No. 54. Pp. 235-242.

[6] Lizunkov V. G. Development of social partnership and networking of educational and production clusters of advanced training for Priority Social and Economic Development Areas (PSEDA) // In the proceedings: A new look at the education system. Proceedings of the II International Scientific and Practical Conference. Responsible editor E. Yu. Pudov. 2019. Pp. 079.1-079.4.]. https://doi.org/10.15405/ epsbs.2020.12.04.63

[7] Gershunsky B.S. Continuity of educational activities in the context of continuing education // Prospects for the development of the continuing education system (Moscow: Pedagogy) pp 148-163. 1990. 
[8] Zhang, W. A variable precision rough set model for Knowledge assisted management in distance education // International Journal of Emerging Technologies in Learning. 13(11), pp. 41-53. 2018. https://doi.org/10.3991/ijet.v13i11.9602

[9] Osipov, P.N. Patterns and principles of internationalization of engineering education // Professional education in Russia and abroad. - 2016. - Iss. 1. - Pp.40-46.

[10] Ankrah S, AL-Tabbaa O (2015) Universities-industry collaboration: a systematic review. Scand J Manag 31:387-408. https://doi.org/10.1016/j.scaman.2015.02.003

[11] Franco M, Haase H (2015) University-industry cooperation: researchers' motivations and interaction channels. J Eng Technol Manag 36:41-51. https://doi.org/10.1016/j.jengtecman.2015.05.002

[12] Pinheiro ML, Lucas C, Pinho JC (2015b) Social network analysis as a new methodological tool to understand university-industry cooperation. Int J Innov Manag 19:1550013. https://doi.org/10.1142/s1363919615500139

[13] Smirnov I.P. Social partnership: what awaits the employer? (Results of the pilot sociological research) / I.P. Smirnov, E.V. Tkachenko. - Moscow: Aspect LLC, 2004. - $177 \mathrm{p}$.

[14] Tkachenko E. V. Fundamentals of regionalization of basic vocational training / E.V. Tkachenko. - Moscow: IC APO, 2001. - 45 p.

[15] Shestak N.V. Learning technology in the system of continuing professional education // Higher Education in Russia. No. 12. Pp. 98-103. 2006.

[16] Chen J., Zhao J. An educational data mining model for supervision of network learning process // International Journal of Emerging Technologies in Learning. 13(11), pp. 67-77. 2018. https://doi.org/10.3991/ijet.v13i11.9599

[17] Verbitsky A.A. Active Learning in Higher Education: A Contextual Approach // Active higher school education: a contextual approach (Moscow: High school) 204 p. 1991.

[18] Semenova, I.S. Regional education management: trends and directions of development // Socio-humanitarian knowledge. - 2009. - No. 1 - Pp. 239-245.

[19] Lizunkov, V., Politsinskaya, E., Malushko, E., Pavlov, A. Modelling as the basis for building a competency model of a specialist demanded by industrial enterprises in Priority Social and Economic Development Area (PSEDA) // International Journal of Emerging Technologies in Learning 15(13), pp. 321-326, 2020 https://doi.org/10.3991/ijet.v15i13.13941

[20] Lizunkov, V., Politsinskaya, E., Gazin, K. The architecture of project-based learning in the supplementary vocational education system in higher education // International Journal of Emerging Technologies in Learning 15(4), pp. 227-234, 2020 https://doi.org/10.3991/ijet.v15i04.11694

[21] E. Malushko, O. Maletina, V. Lizunkov, V. Tsybaneva, use of virtual learning system for educating students with disabilities and special needs // International Multidisciplinary Scientific Conferences on Social Sciences and Arts, 481-487 (2016). https://doi.org/10.5593/sgemsocial2015/b12/s3.149 


\section{Authors}

Vladislav Lizunkov, PhD, Tomsk Polytechnic University Yurga Institute of Technology, Russia, vladeslave@ rambler.ru. The area of scientific interests is the theory and methodology of vocational education.

Marina Morozova, PhD, Tomsk Polytechnic University Yurga Institute of Technology, Russia, morozovamarina-1@ mail.ru. The area of scientific interests is the theory and methodology of vocational education.

Alexandra Zakharova, Doctor in Engineering, Tomsk State University of Control Systems and Radio electronics, Tomsk, Russia, zacharovaa@mail.ru. The area of scientific interests is the decision support systems.

Article submitted 2020-10-28. Resubmitted 2020-11-26. Final acceptance 2020-11-27. Final version published as submitted by the authors. 